\section{Explaining Disease}

A History of Medicine. Edited by Lester S. King. Pp. 307. (Penguin: Harmondsworth, 1971.) 60p.

THE compiler of this work is an authority on the history of medicine, and is also the editor of the Journal of the American Medical Association. Among his previous writings are a general survey of medical thought, several substantial papers and two wise studies of eighteenth century medicine. It follows that he is excellently qualified to edit an anthology such as the one under review.

In it he presents extracts from some of the works that, in his view, make rational attempts to explain the mysteries of disease. Each passage, of which there are twenty spread over 265 pages, is preceded by a short introduc. tion. The whole work is prefaced by a condensed but useful account of medical history in which Dr King also expounds the principles that have guided him in making his selection. A subtitle for his book, he suggests, would be "a study of critical acumen".

There are four main sections. The first, headed "Classical Heritage", covers Hippocrates and Galen; the second, "Revolt", includes Vesalius, Paracelsus and Harvey; the third, "Development", takes in Sydenham, Boerhaave, Cullen, and so on; and the fourth, "Fruition", brings us through Virchow, Bernard, Banting and Best to a recent article in the Journal of the American Medical Association by Simon and Harley.

As with any anthology many names are left out and many questions left begging. There is no Pasteur, for instance: no Snow, no Semmelweiss (true, he has never been translated), no Laënnec, and absolutely no Arabs; but on that score we have no real criticism to offer, for the space is simply not available to accommodate them all. What we would question is the editor's choice of Hahnemann, despite the admission that "homeopathy was a rather curious medical backwater" and despite the total exclusion of mediaeval medicine on grounds that are not so very different ("it did not contribute much to the critical acumen whose development forms the pattern of this book"). In the context of medical history one would have a hard time defining what "critical acumen" really is. If it is to be found in Hahnemann why not also in the theories of the miasmatists, or indeed of the eighteenth century Brunonians who, lacking the technical facilities that we take so much for granted today, were driven to weaving brilliant conceptual patterns and to making apparently logical, but no less mistaken, deductions.

But whatever slight reservations one has to make about Dr King's choice, on the whole his anthology must be welcomed as a solid and reliable piece of work. Perhaps it is a little unadventurous and conventional, but, that being said, it has the very definite ring of authority. We can be certain that considering the ubiquity of Penguins it will reach the homes of many who as yet hardly suspect the existence and fascination of medical history, and this surely will be a good thing. It may even entice some readers to reach out for the complete versions of Dr King's abbreviated texts.

E. Gaskell

\section{Women at Yale}

Women at Yale. By Janet Lever and Pepper Schwartz. Pp. 274. (Allen Lane: The Penguin Press.) $£ 2.50$.

THERE is, or used to be, a Harvard song about the unhealthy effect the lack of females had on students at Yale University. If this book, describing the experience of Yale's first year of co-education, is accurate, the song will not have to be abandoned. There still exists, it seems, a hell of a situation down at Yale.

The presence of 500 women among 4,500 undergraduates seems to have thrown both sexes into a state of sexual and intellectual shock. That was not the intention behind co-education. Yale, as the world knows, is an enlightened place, run by Kingman Brewster who is the shining example of a college president who knows when to give in and when to stand firm. He recognized that the hour of women's equality had come and yielded to the undergraduate demand for women on campus, even though it meant offending the old graduates on whom much of Yale's financial support depends. In the autumn of 1969 women entered Yale and went to live in its residential colleges where the male students also live. Yale's plan, which is proceeding, was to have their numbers increase until both sexes are equally represented among the students.

But co-education proved more uncomfortable in practice than in theory. The men began to realize that they would be deprived of the "Yale experience" which nurtured their fathers and grandfathers and Dinky Stover before them. Theirs was not to be four years of cloistered fraternity with the future leaders of the East Coast establishment. Instead the elite was to be diluted by the presence of outsiders who, in addition to being female, offered little promise of distinction in later life. And what might have been a compensatory advantage - the availability of feminine companionship during the Monday-to-Friday period during which Yalies have traditionally gone without-turned out to be a liability. The men soon realized the awkwardness of having to confront at breakfast the bedpartner of the night before. The solution to this widely experienced dilemma was what the authors call "the incest taboo". Men and women from the same college found it simpler to remain just good friends.

As for the girls, they too found Yale disillusioning. A bright lot, good at their books, they found themselves stared at as sexual objects. Presumably this had happened to them before but the authors assert that at Yale it was worse, that Yale is a caricature of modern American male chauvinist society. The women therefore found themselves losing self-esteem. With eight men to every girl, the female who did not have a date on Saturday night knew that she must be repulsive beyond a doubt. And the Yale girls became hostile to the dates that Yale men imported, as is their tradition, at weekends.

This book makes good light reading and for that reason constitutes a dis service to the cause in which the authors, two women graduate students in sociology, fervently believe-women's liberation. They are obsessed with the idea of a university as a processor of people, an instrument of socialization. They mention hardly a word about academic work or intellectual activity of any sort. They also concoct a kind of mock sociologese that would do better in a teenage advice column than in what they insist is a serious book. They worry about the "frienddate dichotomy", exclaim over the "dangers of ego-protection" and congratulate themselves on their unique role as "both teacher and date".

One can only hope that their utter absorption in the dating ritual and lack of interest in the academic side of Yale is idiosyncratic and not general. Did nobody read a book that year? Were there no women arrivals who found the intellectual resources of a great university some compensation for the discomforts of being a sexual pioneer? It is possible that the presence of women did just what the male chauvinists have claimed for centuries - drove out thought. Or, possibly, the authors themselves are guilty of using the scene to make their point-that Yale, like the United States, has a social structure repressive to women. Perhaps the answer to the question of whether Yale has been liberated or not should not be attempted for another few years, to give time for the first women students to assess their relationship to the university itself and not just to the apprehensive young men who made their first year so self-conscious.

Brenda Maddox 